\title{
COMET ASSAY PARAMETERS OF SPODOPTERA LITTORALIS (BOISD.) LARVAE RESISTANCE SYSTEM CELLS AS AFFECTED BY DIFFERENT COMPOUNDS EXPOSED TO GAMMA IRRADIATION
}

\author{
AMER, R. ABDEL-GALEIL ${ }^{1}$; M. S. MOHAMED ${ }^{1}$; \\ DALIA A. ABDEL-SALAM ${ }^{1}$ and NANCY H. NAGUIB ${ }^{2}$
}

${ }^{1}$ Plant Protection Research Institute, Agriculture Research Center, Dokki, Giza, Egypt. ${ }^{2}$ Depart. of Econ. Entomol. \& Pesticide, Faculty of Agriculture, Cairo University, Giza

E.mail: Redaamer85@Gmail.com; Msalem3030@gmail.com;

Abdallah dalia@yahoo.com and Whitehorse3050@gmail.com

(Manuscript received 16 February 2018)

\begin{abstract}
$\mathrm{T}$ he Comet assay, called the single cell gel electrophoresis (SCGE) assay or microgel electrophoresis (MGE) assay, primarily measures DNA strand breakage in single cells
\end{abstract} according to the cell type in vitro and in vivo experiments. The main objective of this study is to assess the sensitivity of genotoxic to be considered in cotton leafworm, Spodoptera littoralis (Boisd.) larvae by causing depletion in cells responsible for functions of the resistance system of this pest to the pesticides as affected by three compounds; Bacillus thuringiensis, Kurs. (Bactericide); Metarhizium anisopltae, Metsch. (Fungicide) and chitosan (biopolymer) exposed to gamma irradiation at doses of 15,30 and 60 Gy to increase purpose of its activity on genotoxicity parameters of the cotton leaf worm, S. littoralis (Boisd.) treated as $4^{\text {th }}$ instars larvae by $\mathrm{LC}_{50^{\prime}} \mathrm{S}$ of compounds mentioned. B. thuringiensis exposed to gamma doses of $15,30 \& 60 \mathrm{~Gy}$ had potentiating efficacy on $S$. littoralis than $B$. thuringiensis used alone without exposing to gamma doses. While, M. anisopltae and chitosan had nearest results among tested compounds singly and the same compound exposed to gamma doses used. Different comet assay parameters; Cell numbers, comet length $(\mu)$, head diameter $(\mu), \%$ DNA in head, tail length $(\mu), \%$ DNA in tail and \% tail moment were affected by direct effect of compounds used on $S$. littoralis larvae lead to death the most of cells and its DNA degradation or another effect by division increasing in DNA lead to increase the malformation cells or \% DNA as well as examined nuclei numbers compared to normal $S$. littoralis larvae. Also, \% DNA in examined nuclei had destruction grades according to the treatments used that ranged from 0-3 grades. In addition, the resistance system cells of $S$. littoralis that investigated by fluorescence microscopy had clearly injurious appeared in disruption; lost its roundness and cell wall; swelling or shrinking in the most investigated cells. It can be concluded that chitosan exposed to different gamma doses was the most genotoxicity compound affect on resistance system cells of $S$. littoralis larvae, followed by $B$. thuringiensis and $M$. anisopltae exposed to gamma doses.

Key words: gamma irradiation, B. thuringiensis, M. anisopltae, chitosan, $S$. littoralis, genotoxicity. 


\section{INTRODUCTION}

The single-cell gel electrophoresis assay (comet assay) is widely used for the detection of DNA damage and repair in a variety of cells in vitro and in vivo (Olive and Banath, 2006). DNA damage detected by the alkaline version of the comet assay includes single-and double-strand breaks and alkali-labile (e.g. apurinic) sites. The assay has the advantage of being a rapid, sensitive and relatively inexpensive method. It is not only commonly used in genotoxicity testing but it also has widespread applications in environmental biomonitoring and human population monitoring (Amaeze et al., 2015).

The "comet assay" was designed by Ostling and Johanson (1984). Its name was derived from the shape of the nuclear DNA after some steps of manipulation. The comet assay can be applied to all cells, tissues and organs as long as it is possible to generate single cells. The comet assay in its various modifications definitely is a valuable tool for the assessment of DNA damage and is now used in many fields of research. Thus, the release of DNA from a highly supercoiled DNA-protein complex is actually measured in the comet assay and there is a lot of evidence that the comet tail consists of DNA loops and not of DNA fragments (Collins et al., 1997).

Undoubtedly, among more than 1300 pest species recorded on cotton, the Egyptian cotton leafworm, Spodoptera littoralis (Boisd.) is considered as the most important cotton pest that is found almost everywhere cotton is grown in Egypt (Hosny and Isshak, 1967). The control strategy was based mainly on uses of synthetic insecticides but most are toxic to all animals including human beings, and persistent in environment, numbers of them have carcinogenic and mutagenic effects on human, domestic animals, birds and predators. In order to avoid the insecticidal hazards, there is a great need to develop alternative control agents with new mode of action. Among these agents is gamma irradiation as a genetic control method. Genetic pest suppression is unique among biological methods in it involves the release of genetically modified insects to control the same species. The irradiated biocide, Dipel$2 x$ with doses of 5, 10, 20, $40 \& 80$ Gy activated its insecticidal efficiency against $P$. gossypiella newly hatched larvae and eggs of 1-4 day old in laboratory and field experiments during seasons of 2004 and 2005 (Amer, 2006). In addition, Amer, et al. (2011) mentioned that gamma doses used (100, 200 \& $300 \mathrm{~Gy}$ ). had antagonism effect in biover efficiency and sub lethal doses becomes higher than untreated biover against $4^{\text {th }}$ instars larvae of S.littoralis. Moreover, Amer, et al. (2012) reported that biocide compound, Protecto (B.thuringiensis, Kurs.) applied on P. gossypiella, $S$. littoralis and $A$. craccivora to assess the insecticidal activity in three combinations 
(Protecto +150 Gy, Protecto +250 Gy and Protecto +350 Gy). Data showed that $\mathrm{LC}_{50}$ 'S on subjected insects treated with Protecto and exposed to gamma doses were lower than untreated Protecto.

Also, M. anisopliae was studied on S. littoralis susceptibility or M. anisopliae combined with gamma irradiation by Gabarty, et al. (2013).

Chitosan compound might be used as alternatives pesticides because it might possess insecticidal activity and non toxic effect on vertebrates and humans (Badawy, et al. (2005). The insecticidal activity of chitosan was reported against $S$. littoralis by Rabea, et al. (2003). Also, El-Gendy, et al. (2014) evaluate the toxicity and biochemical effects of chitosan against Bactrocera zonata (Saund.). Chitosan effect on female and male adults after 24 and 48 hours. Also, it caused inhibition in AChE and ATPase.

The aim of the present study is evaluate the combined effects of the compounds, Bacillus thuringiensis, Kurs. (Bactericide); Metarhizium anisopltae, Metsch. (Fungicide) and biopolymer, chitosan exposed to gamma irradiation at doses of 15, 30 and $60 \mathrm{~Gy}$ on resistance system cells of the cotton leafworm, Spdoptera littoralis (Boisd.) treated as $4^{\text {th }}$ instars larvae.

\section{MATERIALS AND METHODS}

\section{A. Compounds.}

1- Bactericide: Bacillus thuringiensis subsp. kurstaki :(Biotect) 9.4\% WP (32000 $\mathrm{IU} / \mathrm{mg})$, produced by Organic for biotechnology company. Dose rate: $300 \mathrm{gm} /$ feddan (2400 IU/ml).

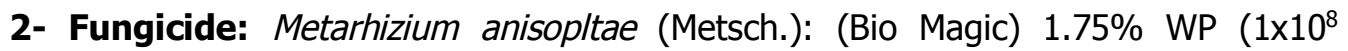
CFU,S/gm). Manufacturer Company: M/S. T. Stanes Company Limit- India. Import Company: Gaara Establishment, Import \& Export. Dose rate: 10gm/ L Water (1x10 CFU'S/ml).

4- Chitosan (Biopolymer): Chitocare $2.5 \%$, product of Egypt Chemical Company (E.C.C.). Rate dose: $1 \mathrm{~L} /$ feddan for crop or vegetable fields.

All the compounds used exposed to gamma irradiation doses of $15,30, \& 60 \mathrm{~Gy}$. All irradiations were done by a $\mathrm{Se}^{137}$ Hendy Cell Research, delivered at a dose rate $0.75 / \mathrm{rad} / \mathrm{sec}$. The radiation was done at National Center for Radiation Research and Technology. 


\section{B. The pest.}

Laboratory strain of the cotton leafworm, $S$. littoralis fourth instars larvae was reared at Cotton leaf worm Department, Plant Protection Research Institute, Agriculture Research Center on castor oil leaves, Ricinus communis (L.). Rearing of insects was conducted following the technique described by El-Defrawi et al. (1964). Rearing conditions were adjusted at $27 \pm 1^{\circ} \mathrm{C}$ and $65-75 \% \mathrm{RH}$.

C. Toxicity of gamma irradiation doses and different compounds on $\boldsymbol{S}$.

\section{littoralis.}

Twenty five of $S$. littoralis fourth instar larvae with castor oil leaves Petri-dishes exposed to gamma irradiation doses of 15, 30 \& 60 Gy. Four replicates for each gamma doses used and the control was done. The larval mortality percent was recorded daily after treatments.

Dipping technique was used at the present work. The castor oil leaves dipping in tested compound concentrations of $50,25,12.5,6.25 \& 3.125 \mathrm{gm} / \mathrm{L}$ of $B$. thuringiensis (Biotect), B. thuringiensis $+15 \mathrm{~Gy}, B$. thuringiensis $+30 \mathrm{~Gy}$ and $B$. thuringiensis +60 Gy. Concentrations of $30,15,7.5,3.75 \& 1.875 \mathrm{gm} / \mathrm{L}$ of $M$. anisopltae (Bio magic), M. anisopltae +15 Gy, M. anisopltae +30 Gy and M. anisopltae +60 Gy. Concentrations of 50, 25, 12.5, $6.25 \& 3.125 \mathrm{ml} / \mathrm{L}$ of Chitosan (Chitocare), Chitosan $+15 \mathrm{~Gy}$, Chitosan $+30 \mathrm{~Gy}$ and Chitosan $+60 \mathrm{~Gy}$. The control was done by castor oil leaves dipping in water only. Four replicates/ concentration/ tested bioagent and left the leaves until water evaporated and put in glass jars $(11 \times 22 \mathrm{~cm})$. Each jar was prepared by 25 fourth instar larvae of $S$. littoralis after larvae starving about 4 hours and maintained under $26 \pm 1^{\circ} \mathrm{C}$. Then the numbers of alive and dead larvae were counted at three days after treatment.

$\mathrm{LC}_{50}$; $\mathrm{LC}_{90}$ and slope values were assessed according to Finney (1971) by using Ldp line software (www.Ehabbakr software/Ldp line). The efficiency of different insecticides could be measured by using Sun 's equation (1950) as follows:

Toxicity index $=L_{50}\left(L C_{90}\right)$ of the compound $A / L C_{50}\left(L C_{90}\right)$ of the compound $B * 100$

Where $A$ : is the most effective compound.

$\mathrm{B}$ : is the other tested compound.

Fourth instar larvae of $S$. littoralis were treated by $\mathrm{LC}_{50}$ 'S of each compound or the same compound exposed to gamma irradiation doses that were used. Ten days later of treatment, the larvae kept by freezing at $-18^{\circ} \mathrm{C}$ until comet analysis used.

Comet assay was done at Animal Health Research Institute, A.R.C. 


\section{Single cell gel electrophoresis (Comet).}

The alkaline comet assay was conducted as described by Amaeze, et al. (2015). Comets were analyzed using a Leica fluorescence microscope (Leica DMLB 020-519010 LB30T). DNA damage was scored using the Comet IV capture system (version 4.11; Perceptive Instruments, UK). Fifty cell nucleotides were assessed per slide, and each sample was analyzed in duplicate. All samples were measured blind. The tail intensity ( $\%$ tail DNA), defined as the percentage of DNA migrated from the head of the comet into the tail, was used as a measure of DNA damage induced, that is a meaningful end-point to assess genotoxicity.

The technique of single cell gel electrophoresis (comet) regarding preparation of the base slides, cell isolation, electrophoresis of micro-gel slides and buffers preparation were performed according the protocol mentioned by Singh, et al. (1988). The protocol includes:

\section{Preparation of base slides.}

1.1. Prepare $1 \%$ ( $500 \mathrm{mg}$ per $50 \mathrm{ml} \mathrm{PBS}$ ) and $0.5 \%$ LMPA ( $250 \mathrm{mg}$ per $50 \mathrm{ml}$ PBS) and $1.0 \%$ NMA (500 mg per $50 \mathrm{ml}$ in Milli $\mathrm{Q}$ water). Microwave or heat until near boiling and the agarose dissolves. For LMPA, aliquot $5 \mathrm{ml}$ specimens into scintillation vials (or other suitable containers) and refrigerate until needed. When needed, briefly melt agarose in microwave or by another appropriate method. Place LMPA vial in a $37^{\circ} \mathrm{C}$ dry/water bath to cool and stabilize the temperature.

1.2. Dip the slides in methanol and burn them over a blue flame to remove the machine oil and dust.

1.3. While NMA agarose is hot, dip conventional slides up to one-third the frosted area and gently remove. Wipe underside of slide to remove agarose and lay the slide in a tray on a flat surface to dry. The slides may be air dried or warmed at $50^{\circ} \mathrm{C}$ for quicker drying. Store the slides at room temperature until needed; avoid high humidity conditions. We generally prepare slides the day before use.

\section{Cell isolation / treatment.}

Cut larvae specimens into large pieces; add fresh solution of aspirate, mince into finer pieces, remove and settle it down mix $5 \mu$ of the cell suspension with $75 \mu \mathrm{l}$ LMPA, and process accordingly. The volume of the cell suspension to mix with $75 \mu$ of LMPA must be $10 \mu \mathrm{l}$ or less, while the optimal cell number is 10,000 cells per slide. 


\section{Electrophoresis of micro gel slides.}

3.1. After at least 2 hour at $4^{\circ} \mathrm{C}$, gently remove slides from the lysing Solution. Place slides side by side on the horizontal gel box near one end, sliding them as close together as possible.

3.2. Fill the buffer reservoirs with freshly made $\mathrm{pH}>13$ Electrophoresis Buffer until the liquid level completely covers the slides (avoid bubbles over the agarose).

3.3. Let slides sit in the alkaline buffer for 20 minutes to allow for unwinding of the DNA and the expression of alkali-labile damage

3.4. Turn on power supply to 24 volts $(\sim 0.74 \mathrm{~V} / \mathrm{cm})$ and adjust the current to 300 milli amperes by raising or lowering the buffer level. Depending on the purpose of the study and on the extent of migration in control specimens, electrophoreses the slides for 30 minutes.

3.5. Turn off the power. Gently lift the slides from the buffer and place on a drain tray. Drop wise coat the slides with Neutralization Buffer, let sit for at least 5 minutes. Drain slides and repeat two more times.

3.6. Slides may be stained with $80 \mu \mathrm{L}$ Ethidium Bromide, leave for $5 \mathrm{~min}$ and then dipped in chilled distilled water to remove excess stain. The cover slip is then placed over it and the slides are scored immediately or dried before staining as in step 7.

3.7. Drain slides; keep them for 20 min in cold $100 \%$ ethanol or cold $100 \%$ methanol for dehydration. Dry the slides by air and place them in an oven at $50^{\circ} \mathrm{C}$ for $30 \mathrm{~min}$. Store in a dry area.

3.8. When convenient, rehydrate the slides with chilled distilled water for $30 \mathrm{~min}$ and stain with $\mathrm{Et}-\mathrm{Br}$ as in step 6 and cover with a fresh cover slip. Before viewing slides, blot away excess liquid on the back and edges. After scoring, remove cover slip, rinse in $100 \%$ alcohol to remove stain, let dry, and store for archival purposes if needed.

\section{Evaluation of DNA Damage.}

4.1. For visualization of DNA damage, the observations by made of EtBr-stained DNA using a 40X objective on a fluorescent microscope.

4.2. Although any image analysis system may be suitable for the quantization of SCGE data, we use comet score to assess the quantitative and qualitative extent of DNA damage in the cells by measuring the length of DNA migration and the percentage of migrated DNA. Finally, the program calculates tail moment. Generally, 50 to 100 randomly selected cells are analyzed per specimen.

4.3. Compare the amount of migration per cell, the number of cells with increased migration, the extent of migration among damaged cells and viability. 
Finally, the program calculates the number of cells, comet length $(\mu)$, head diameter $(\mu), \%$ DNA in head, tail length $(\mu), \%$ DNA in tail, tail moment (\% DNA in tail/ \% DNA in head).

Grading of DNA damage: There are five grades of DNA destruction according to Singh et al. (1988)

$\%$ DNA damage $=\frac{\text { Tail length }}{\text { Comet length }}$

Grade 0: NO damage, normal cell, tail length less than $5 \%$

Grade 1: Slightly damaged, tail length $5-20 \%$

Grade 2: Moderately damaged, tail length $20-40 \%$

Grade 3: Heavily damaged, tail length $40-92 \%$

Grade 4: Totally damaged, tail length higher than $95 \%$

All genotoxicity parameters of $S$. littoralis were analyzed using Costat statistical program software, 1990 and Duncan's multiple range test (Duncan, 1955) at 5\% probability level to compare the differences among time means.

\section{RESULTS AND DISCUSSION}

\section{A. Efficacy of gamma irradiation and different compounds on S. littoralis.}

Toxicity of gamma irradiation and different compounds singly or in combination were investigated previously by Amer, et al. (2015) as following

Table 1. Effect of gamma irradiation on larval mortality of $S$. littoralis treated as $4^{\text {th }}$ instar larvae.

\begin{tabular}{|c|c|c|c|c|}
\hline \multirow{2}{*}{$\begin{array}{c}\text { Gamma } \\
\text { doses }\end{array}$} & \multicolumn{4}{|c|}{ \% Larval mortality after } \\
\cline { 2 - 5 } & 4-day & 6-day & 8-day & 10-day \\
\hline Control & $0^{\mathrm{c}}$ & $0^{\mathrm{c}}$ & $0^{\mathrm{d}}$ & $0^{\mathrm{c}}$ \\
\hline $\mathbf{1 5}$ & $20^{\mathrm{b}}$ & $30^{\mathrm{b}}$ & $42^{\mathrm{c}}$ & $60^{\mathrm{b}}$ \\
\hline $\mathbf{3 0}$ & $23^{\mathrm{b}}$ & $32^{\mathrm{ab}}$ & $52^{\mathrm{b}}$ & $63^{\mathrm{b}}$ \\
\hline $\mathbf{6 0}$ & $28^{\mathrm{a}}$ & $35^{\mathrm{a}}$ & $58^{\mathrm{a}}$ & $69^{\mathrm{a}}$ \\
\hline LSD $_{\mathbf{0 . 0 5}}$ & 3.26 & 2.46 & 4.15 & 3.87 \\
\hline
\end{tabular}


892 COMET ASSAY PARAMETERS OF SPODOPTERA LITTORALIS (BOISD.) LARVAE RESISTANCE SYSTEM CELLS AS AFFECTED BY DIFFERENT COMPOUNDS EXPOSED TO GAMMA IRRADIATION

Larval mortality rates depended on gamma doses. Dose of 60 Gy had the highest larval mortality, followed by 30 and $15 \mathrm{~Gy}$, respectively (Table 1 ).

The present results, in general are in agreement with Amer (2006), Amer, et al. (2011) and Amer, et al. (2012).

$\mathrm{LC}_{50}$ ' $\mathrm{S}$ of tested compounds; $B$. thuringiensis, M. anisopliae and chitosan singly or combined with gamma irradiation doses of 15, 30 and 60 Gy described in Table (2).

Table (2) showed that $\mathrm{LC}_{50}$ of $B t$ was $1133 \times 10^{6} \mathrm{IU} / \mathrm{L}$ against $4^{\text {th }}$ instar larvae of $S$. littoralis. On the other hand, when $B t$ was exposed to gamma irradiation, it showed potentiating efficacy, where $\mathrm{LC}_{50}$ was decreased to $810.2 \times 10^{6} \mathrm{IU} / \mathrm{L}(B t+15 \mathrm{~Gy}$ ), $337.9 \times 10^{6} \mathrm{IU} / \mathrm{L}(B t+30 \mathrm{~Gy})$ and $163.9 \times 10^{6} \mathrm{IU} / \mathrm{L}(B t+60 \mathrm{~Gy})$ at 3 days post larval treatments. Also, $B t+60 \mathrm{~Gy}$ was considered the most efficacious compound against $4^{\text {th }}$ instar larvae, followed by $B t+30 \mathrm{~Gy}, B t+15 \mathrm{~Gy}$ and then $B t$ non-irradiated that had the least efficacy compared to the same compounds exposed to gamma radiation.

Table 2. Different compounds exposed to gamma doses against $S$. littoralis larvae at 3- day post treatments.

\begin{tabular}{|c|c|c|c|c|c|}
\hline \multirow[t]{2}{*}{ Treatments } & \multirow{2}{*}{$\begin{array}{c}\mathbf{L C}_{50} \\
\text { 95\% Confidence } \\
\text { limits }\end{array}$} & \multirow{2}{*}{$\begin{array}{c}\text { LC } \text { 90 }_{90} \\
\text { 95\%Confidence limits }\end{array}$} & \multirow[t]{2}{*}{ Slope } & \multicolumn{2}{|c|}{$\begin{array}{c}\text { Toxicity } \\
\text { index }\end{array}$} \\
\hline & & & & $\mathbf{L C}_{\mathbf{5 0}}$ & $\mathbf{L C}_{90}$ \\
\hline & \multicolumn{2}{|c|}{ (IU/L) } & & & \\
\hline B. thuringiensis & $\begin{array}{c}1133 \times 10^{6} \\
965.1 \times 10^{6} \pm 1551 \times 10^{6}\end{array}$ & $\begin{array}{c}2719 \times 10^{6} \\
1934 \times 10^{6} \pm 4497 \times 10^{6}\end{array}$ & 1.33 & 14.5 & 23.8 \\
\hline $\begin{array}{l}\text { B. thuringiensis }+15 \\
\text { Gy }\end{array}$ & $\begin{array}{c}810.2 \times 10^{6} \\
581.8 \times 10^{6} \pm 1257 \times 10^{6}\end{array}$ & $\begin{array}{c}2247 \times 10^{6} \\
1639 \times 10^{6} \pm 3165 \times 10^{6}\end{array}$ & 1.76 & 20.2 & 28.8 \\
\hline $\begin{array}{l}\text { B. thuringiensis }+30 \\
\text { Gy }\end{array}$ & $\begin{array}{c}337.9 \times 10^{6} \\
136.9 \times 10^{6} \pm 643.8 \times 10^{6}\end{array}$ & $\begin{array}{c}1682 \times 10^{6} \\
877.1 \times 10^{6} \pm 2669 \times 10^{6} \\
\end{array}$ & 1.88 & 48.5 & 38.5 \\
\hline \multirow[t]{2}{*}{$\begin{array}{l}\text { B. thuringiensis }+60 \\
\text { Gy }\end{array}$} & $\begin{array}{c}163.9 \times 10^{6} \\
29.7 \times 10^{6} \pm 484.2 \times 10^{6}\end{array}$ & $\begin{array}{c}647.7 \times 10^{6} \\
391.7 \times 10^{6} \pm 1748 \times 10^{6} \\
\end{array}$ & 1.98 & 100 & 100 \\
\hline & \multicolumn{2}{|c|}{ (CFU'S /L) } & & & \\
\hline M. anisopliae & $\begin{array}{c}62.23 \times 10^{8} \\
32.55 \times 10^{8} \pm 90.38 \times 10^{8}\end{array}$ & $\begin{array}{c}950.40 \times 10^{8} \\
340.2 \times 10^{8} \pm 1192.3 \times 10^{8}\end{array}$ & 0.5 & 96.8 & 99.7 \\
\hline M. anisopliae +15 Gy & $\begin{array}{c}62.1 \times 10^{8} \\
32.56 \times 10^{8} \pm 90.42 \times 10^{8} \\
\end{array}$ & $\begin{array}{c}950.3 \times 10^{8} \\
340.2 \times 10^{8} \pm 1191.3 \times 10^{8}\end{array}$ & 0.52 & 97.0 & 99.7 \\
\hline M. anisopliae +30 Gy & $\begin{array}{c}61.41 \times 10^{8} \\
30.42 \times 10^{8} \pm 89.58 \times 10^{8}\end{array}$ & $\begin{array}{c}949.4 \times 10^{8} \\
320.9 \times 10^{8} \pm 1189.4 \times 10^{8}\end{array}$ & 0.56 & 98.0 & 99.8 \\
\hline \multirow[t]{2}{*}{ M. anisopliae +60 Gy } & $\begin{array}{c}60.22 \times 10^{8} \\
30.12 \times 10^{8} \pm 87.87 \times 10^{8}\end{array}$ & $\begin{array}{c}947.3 \times 10^{8} \\
310.4 \times 10^{8} \pm 1177.7 \times 10^{8}\end{array}$ & 0.62 & 100 & 100 \\
\hline & \multicolumn{2}{|c|}{$(\mathbf{m l} / \mathbf{L})$} & & & \\
\hline Chitosan & $\begin{array}{c}24.41 \\
18.88 \pm 40.28 \\
\end{array}$ & $\begin{array}{c}50.81 \\
32.21 \pm 80.56 \\
\end{array}$ & 3.1 & 77.1 & 81.9 \\
\hline Chitosan +15 Gy & $\begin{array}{c}21.22 \\
15.46 \pm 35.38 \\
\end{array}$ & $\begin{array}{c}47.98 \\
30.35 \pm 73.87 \\
\end{array}$ & 3.1 & 88.7 & 86.7 \\
\hline Chitosan +30 Gy & $\begin{array}{c}20.45 \\
13.25 \pm 33.54 \\
\end{array}$ & $\begin{array}{c}43.68 \\
25.45 \pm 73.75 \\
\end{array}$ & 3.2 & 92.0 & 95.2 \\
\hline Chitosan +60 Gy & $\begin{array}{c}18.82 \\
10.89 \pm 30.98\end{array}$ & $\begin{array}{c}41.59 \\
21.98 \pm 70.70\end{array}$ & 3.2 & 100 & 100 \\
\hline
\end{tabular}

Obtained results were confirmed previously by Amer (2006) and Amer et al. (2012).

The fungus, M. anisopliae effected on $4^{\text {th }}$ instar larvae (LC $\mathrm{L}_{50}: 62.23 \times 10^{8} \mathrm{CFU}, \mathrm{S} / \mathrm{L}$ ), but when $M$. anisopliae was exposed to gamma doses, it had little increase in its 
efficacy compared to $M$. anisopliae when it was applied alone (Table 2). Present results are nearly those of Amer, et al. (2011) who reported that gamma irradiation doses of 100, 200 and 300 Gy had antagonism effect on biover efficacy against cotton leaf worm $4^{\text {th }}$ instar larvae and gamma doses used had sub lethal doses higher than untreated biover. In addition, Gabarty, et al. (2013) investigated the efficacy of sub sterilizing doses of gamma irradiation or/ and entomopathogenic fungi $B$. bassiana and $M$. anisopliae on the immune enzyme response of $S$. littolaris larvae. It was found that gamma radiation $(50,100 \& 150 \mathrm{~Gy})$ and tested entomopathogenic fungi synergistically inhibit the immune system of $S$. littolaris larvae to become susceptible to the treatments.

Biopolimer, chitosan had efficacy on $4^{\text {th }}$ instar larvae and LC50 was $24.41 \mathrm{~m} / \mathrm{L}$. When chitosan was exposed to gamma doses $15-60 \mathrm{~Gy}$, its efficacy had medium increase reaching $18.82 \mathrm{~m} / \mathrm{L}$ after 3- days from treatment, in case of chitosan +60 Gy. El-Gendy, et al. (2014) stated that chitosan gave inhibition of Ach.E and ATPase activities of Bactrocera zonata.

\section{B. Comet assay parameters.}

Fourth instars larvae of $S$. littoralis treated with $\mathrm{LC}_{50} \mathrm{~S}$ of different compounds and gamma irradiation in singly or in combination. Ten-days later after larvae treatment as described previously for comet assay to investigate the genotoxicity or comet parameters of resistance system cells as a result of different treatments.

Table (3) and figure (1) showed the comet assay parameters of no. cell, comet length or cell length (micron, $\mu$ ) that contain both head diameter $(\mu)$ and tail length $(\mu)$. In each head and tail of the cell, it was DNA percentage determined; also, tail moment parameter was calculated.

\section{Cell numbers.}

Normal resistance system cell numbers of $S$. littoralis larvae was 39 cells. Treatments of $60 \mathrm{~Gy}, 30 \mathrm{~Gy}$, M. anisopliae, B. thuringiensis + $60 \mathrm{~Gy}$, chitosan, chitosan + 15 Gy and chitosan + 30 Gy as well as M. anisopliae + 15 Gy causes lost no. of cells that appeared in the slides to become 19, 21, 28, 30, 31, 33 and 35 cells, respectively compared to untreated samples. Contrary was happened in treatments of 15 Gy (76 cell), M. anisopliae +60 Gy (56 cell), B. thuringiensis + 15 Gy (53 cell), chitosan +60 Gy (52 cell), B. thuringiensis (51 cell), M. anisopliae + 30 Gy (49 cell) and $B$. thuringiensis $+30 \mathrm{~Gy}$ (43 cell) as a result of DNA division increasing that happened compared to normal no. cell.

\section{Comet length.}

Comet length (resistance system cell length) that was $16.12 \mu$ in normal $S$. littoralis larvae; each cell contained head and tail; both of them called comet length. Treated $S$. littoralis larvae comet length had decreased to 13.08, 13.64, 13.97, 14.76, 15.71 and $15.93 \mu$ for M. anisopliae +60 Gy, M. anisopliae +30 Gy, B. thuringiensis + 
$15 \mathrm{~Gy}, 15 \mathrm{~Gy}$, chitosan and M. anisopliae $+15 \mathrm{~Gy}$, respectively. Meanwhile, treatments of chitosan $+15 \mathrm{~Gy}$, chitosan $+30 \mathrm{~Gy}$ and M. anisopliae had values close to control.

\section{Head diameter and \% DNA.}

Comet length or resistance system cell length as described previously consists of head diameter and tail length as in Table (3) and figure (1).

Head diameter of untreated cell samples was $14.46 \mu$ that close to chitosan +15 Gy and M. anisopliae +15 Gy treatment values. The treatments effect on head diameter of $S$. littoralis larvae cell by decreasing the head diameter to $10.02,11.13$, $11.96,12.19,12.35,12.93,13.46$ and $13.6 \mu$ for $60 \mathrm{~Gy}$, M. anisopliae $+60 \mathrm{~Gy}$, chitosan + $60 \mathrm{~Gy}$, B. thuringiensis + $15 \mathrm{~Gy}$, M. anisopliae +30 Gy, $15 \mathrm{~Gy}$, chitosan and chitosan $+30 \mathrm{~Gy}$, respectively. The rest treatments causes cell head diameter increased compared to control.

Normal \% DNA in cell head was $92.49 \%$. Some treatment causes DNA division increased to reach 95.07 and $93.35 \%$ in M. anisopliae and M. anisopliae $+30 \mathrm{~Gy}$; while, treatments of $B$. thuringiensis $+60 \mathrm{~Gy}$ and $60 \mathrm{~Gy}$ had values close to control. Other treatments decreased \% DNA in the cell head as described in table (3) and figure (1).

\section{Tail length and \% DNA.}

Tail length indicated the cell malformation. The normal had tail length $1.662 \mu$; the tail length was increased in all the treatments except for $60 \mathrm{~Gy}(1.421 \mu), M$. anisopliae $(1.247 \mu)$ and $M$. anisopliae +30 Gy $(1.3 \mu)$ that had tail length lower than control.

Normal \% DNA in the tail that migration from the head was $7.503 \%$, this percent decrease just only in $M$. anisopliae; while, treatments of $60 \mathrm{~Gy}$ and $B$. thuringiensis + $60 \mathrm{~Gy}$ had values close to the control as in Table (3) and figure (1). Other treatments had increased in \% DNA in tail that means the highly migration from head to tail as indication to the malformation happened in the cells.

\section{Tail moment.}

That parameter as a result of tail length and its containing from \% DNA migrated from head of $S$. littoralis larvae comet length. When tail moment decreased, it mean sever affected on the resistance system cell genotoxicity as shown in Table (3) and figure (1); the most treatments had increased from tail moment, especially in $30 \mathrm{~Gy}$ and chitosan $+60 \mathrm{~Gy}$ treatments. Another trend was found in $60 \mathrm{~Gy}$ treatments that had value near from the control.

Table (4) described the total number of examined nuclei in the resistance system cells of $S$. littoralis larvae and its different \% DNA destruction grades as a result of genotoxicity of different treatments.

Different examined nuclei were 628.6 nuclei in the investigated resistance system cells of untreated $S$. littoralis larvae. The value was decreased in the treatments that 
causes damage nuclei in the cells; the treatments were 60 Gy (333.4), 30 Gy (424.8), M. anisopliae (472.7), chitosan + 15 Gy (539.6) and M. anisopliae + 15 Gy (557.6). While, treatments of $M$. anisopliae $+30 \mathrm{~Gy}$ and chitosan $+30 \mathrm{~Gy}$ had values close to control. Rest of treatments had increased from no. of nuclei in the cells because of the mutations in the nuclei as affected by genotoxicity of the treatments (Table 4 and figure 1).

Different DNA destruction percent affected by genotoxicity of the treatments on S. littoralis larvae resistance system cells as follows:

Grade 0: That grade classified as no of damage in DNA normal cell, the tail length less than $5 \%$. This percent was $62.07 \%$ DNA destruction in the normal cells. All the treatments had depressed values compared to control, especially in chitosan treatments combined with gamma doses of 15 or $30 \mathrm{~Gy}$.

Grade 1: Classified as DNA had slightly damage, tail length: $5-20 \%$. This percent was $36.59 \%$ in normal cells. Most of treatment increased \% DNA destruction ranged between 37 to 54\%. Meanwhile, a few treatments had decreased in \% DNA destruction compared to control ranged from 26.09 to $35.96 \%$.

Grade 2: At this classified, DNA percentages had moderately destruction, the tail length 20-40\%. The grade value percent was $1.33 \%$ DNA destruction in the control. All the treatments had a high increasing in \% DNA destruction ranging from 9.935 to $38.65 \%$ as in Table (4) and figure (2).

Grade 3: Classified as a heavily \% DNA destruction rang: 40-92\%. Chitosan + 60 Gy had the highly \% DNA destruction (8.399\%), followed by chitosan + 30Gy $(7.829 \%)$, M. anisopliae + 15 Gy (5.681\%), chitosan (3.991\%), B. thuringiensis + 30 Gy (3.902\%), M. anisopliae+ 60 Gy (2.604 \%) and chitosan + 15 Gy (1.868\%). Meanwhile, other treatments had not \% DNA destruction classified as grade 3 as well as control (Table 4 and figure 2 ).

Table (5), illustrated different genotoxicity as affected by different compounds on S. littoralis larvae resistance system cells as classified \% DNA grade comparing with the control by increasing or decreasing to make easily investigate the recorded data.

Figures $(3,4,5 \& 6)$ showed the different comet cell shape of $S$. littoralis larvae in the control and different treatments by using Fluorescent microscope at 40X. Figures appeared the different destruction in the resistance system cells as affected by most treatments, especially in chitosan $+60 \mathrm{~Gy}$, followed by chitosan $+30 \mathrm{~Gy}$ that had the most genotoxicity on $S$. littoralis larvae as appeared in the most aforementioned parameters compared to genotoxicity of rest of the treatments used compared to control.

The Comet assay has been applied to species already used in bio-monitoring or toxicity testing and has proven to be a resistance system for screening chemicals and complex mixtures for their genotoxicity. Interestingly, all the studies reported in this 
896 COMET ASSAY PARAMETERS OF SPODOPTERA LITTORALIS (BOISD.) LARVAE RESISTANCE SYSTEM CELLS AS AFFECTED BY DIFFERENT COMPOUNDS EXPOSED TO GAMMA IRRADIATION

review demonstrate that chemicals may be investigated in vitro and in vivo in numerous organisms: plants, worms, molluscs, fish, amphibians, and mammalians. Furthermore, some concern that environmentally complex mixtures can be tested with the SCGE protocol. The simplest method for measuring DNA damage is to calculate the percentage of damaged cells, also called percentage of comets. In order to determine this parameter, different categories of damaged cells are arbitrarily defined, which is a disadvantage according to Tice (1995). Another frequently used parameter is the tail length.

Table 3. Mean comet assay parameters of $S$. littoralis larvae resistance system cells affected by different compounds with gamma irradiation.

\begin{tabular}{|c|c|c|c|c|c|c|c|}
\hline Treatments & $\begin{array}{l}\text { Cell } \\
\text { no. }\end{array}$ & $\begin{array}{c}\text { Comet } \\
\text { length } \\
(\mu)\end{array}$ & $\begin{array}{c}\text { Head } \\
\text { diameter } \\
(\mu)\end{array}$ & $\begin{array}{l}\% \text { DNA } \\
\text { in head }\end{array}$ & $\begin{array}{c}\text { Tail } \\
\text { length } \\
(\mu)\end{array}$ & $\begin{array}{l}\% \text { DNA } \\
\text { in tail }\end{array}$ & $\begin{array}{c}\text { Tail } \\
\text { moment }\end{array}$ \\
\hline Control & $39^{\text {de }}$ & $16.12^{\mathrm{abc}}$ & $14.46^{\mathrm{abcd}}$ & $92.49^{\mathrm{ab}}$ & $1.662^{\mathrm{a}}$ & $7.503^{\text {cde }}$ & $0.081^{\mathrm{ab}}$ \\
\hline 15 Gy & $76^{\mathrm{a}}$ & $14.76^{\mathrm{abc}}$ & $12.93^{\mathrm{abcd}}$ & $89.90^{\mathrm{abc}}$ & $1.862^{\mathrm{a}}$ & $10.09^{\mathrm{bcd}}$ & $0.112^{\mathrm{ab}}$ \\
\hline 30 Gy & $21^{i}$ & $20.23^{\mathrm{ab}}$ & $17.67^{\mathrm{ab}}$ & $84.72^{c}$ & $2.554^{\mathrm{a}}$ & $15.28^{\mathrm{a}}$ & $0.180^{\mathrm{a}}$ \\
\hline $60 \mathrm{~Gy}$ & $19^{i}$ & $17.55^{\mathrm{abc}}$ & $10.02^{\mathrm{d}}$ & $92.45^{\mathrm{ab}}$ & $1.421^{\mathrm{a}}$ & $7.548^{\text {cde }}$ & $0.082^{\mathrm{ab}}$ \\
\hline B. thuringiensis & $51^{c}$ & $20.60^{\mathrm{a}}$ & $18.63^{\mathrm{a}}$ & $88.79^{\mathrm{bc}}$ & $2.245^{\mathrm{a}}$ & $11.21^{\mathrm{abcd}}$ & $0.126^{\mathrm{ab}}$ \\
\hline $\begin{array}{l}\text { B. thuringiensis } \\
+15 \text { Gy }\end{array}$ & $53^{\mathrm{bc}}$ & $13.97^{c}$ & $12.19^{\mathrm{bcd}}$ & $91.56^{\mathrm{ab}}$ & $1.773^{\mathrm{a}}$ & $8.435^{\text {bcde }}$ & $0.092^{\mathrm{ab}}$ \\
\hline $\begin{array}{l}\text { B. thuringiensis } \\
+30 \mathrm{~Gy}\end{array}$ & $43^{d}$ & $17.81^{\mathrm{abc}}$ & $15.92^{\mathrm{abc}}$ & $90.95^{\mathrm{ab}}$ & $1.884^{\mathrm{a}}$ & $9.046^{\text {bcde }}$ & $0.099^{\mathrm{ab}}$ \\
\hline $\begin{array}{l}\text { B. thuringiensis } \\
+60 \mathrm{~Gy}\end{array}$ & $30^{\mathrm{gh}}$ & $18.83^{\mathrm{abc}}$ & $17.03^{\mathrm{ab}}$ & $92.75^{\mathrm{ab}}$ & $1.800^{\mathrm{a}}$ & $7.251^{\text {cde }}$ & $0.078^{\mathrm{ab}}$ \\
\hline M. anisop/tae & $28^{\mathrm{h}}$ & $16.88^{\mathrm{abc}}$ & $15.63^{\mathrm{abcd}}$ & $95.07^{\mathrm{a}}$ & $1.247^{\mathrm{a}}$ & $4.933^{e}$ & $0.052^{b}$ \\
\hline $\begin{array}{c}\text { M. anisop/tae + } \\
15 \mathrm{~Gy}\end{array}$ & $35^{\mathrm{ef}}$ & $15.93^{\mathrm{abc}}$ & $13.99^{\mathrm{abcd}}$ & $90.73^{\mathrm{abc}}$ & $1.934^{\mathrm{a}}$ & $9.271^{\text {bcde }}$ & $0.102^{\mathrm{ab}}$ \\
\hline $\begin{array}{c}\text { M. anisop/tae + } \\
30 \mathrm{~Gy}\end{array}$ & $49^{c}$ & $13.64^{c}$ & $12.35^{\mathrm{bcd}}$ & $93.35^{\mathrm{ab}}$ & $1.300^{\mathrm{a}}$ & $6.652^{\mathrm{de}}$ & $0.071^{\mathrm{ab}}$ \\
\hline $\begin{array}{c}\text { M. anisopltae + } \\
60 \mathrm{~Gy}\end{array}$ & $56^{\mathrm{b}}$ & $13.08^{c}$ & $11.13^{\text {cd }}$ & $91.65^{\mathrm{ab}}$ & $1.948^{\mathrm{a}}$ & $8.346^{\text {bcde }}$ & $0.091^{\mathrm{ab}}$ \\
\hline Chitosan & $31^{\mathrm{fgh}}$ & $15.71^{\mathrm{abc}}$ & $13.46^{\mathrm{abcd}}$ & $88.00^{\mathrm{bc}}$ & $2.253^{\mathrm{a}}$ & $11.99^{\mathrm{abc}}$ & $0.136^{\mathrm{ab}}$ \\
\hline Chitosan+15Gy & $33^{\mathrm{fg}}$ & $16.35^{\mathrm{abc}}$ & $14.02^{\mathrm{abcd}}$ & $88.83^{\mathrm{abc}}$ & $2.749^{a}$ & $11.17^{\mathrm{abcd}}$ & $0.126^{\mathrm{ab}}$ \\
\hline Chitosan+30 Gy & $35^{\text {ef }}$ & $16.65^{\mathrm{abc}}$ & $13.60^{\mathrm{abcd}}$ & $88.88^{\mathrm{abc}}$ & $2.990^{\mathrm{a}}$ & $11.31^{\mathrm{abcd}}$ & $0.127^{\mathrm{ab}}$ \\
\hline Chitosan+60 Gy & $52^{\mathrm{bc}}$ & $14.09^{b c}$ & $11.96^{\mathrm{bcd}}$ & $87.32^{\mathrm{bc}}$ & $2.132^{\mathrm{a}}$ & $12.68^{\mathrm{ab}}$ & $0.145^{\mathrm{ab}}$ \\
\hline L.S.D. 0.05 & 4.199 & 5.232 & 4.849 & 5.256 & 2.315 & 4.219 & 0.097 \\
\hline P. & 0 & 0.150 & 0.046 & 0.045 & 0.977 & 0.0027 & 0.543 \\
\hline Significant & $* * *$ & ns & $*$ & $*$ & ns & $* *$ & ns \\
\hline $\mathbf{F}$ & 103.4 & 1.537 & 2.029 & 2.037 & 0.374 & 3.218 & 0.929 \\
\hline S.S & 10090 & 544.8 & 530 & 632.02 & 72.87 & 516.7 & 0.157 \\
\hline $\begin{array}{l}\text { Error mean } \\
\text { square }\end{array}$ & 6.375 & 9.896 & 8.5 & 10.10 & 1.938 & 6.438 & 0.0034 \\
\hline
\end{tabular}


Fig. 1. Comet assay of $S$. littoralis larvae resistance system cells as affected by different compounds with gamma irradiation.

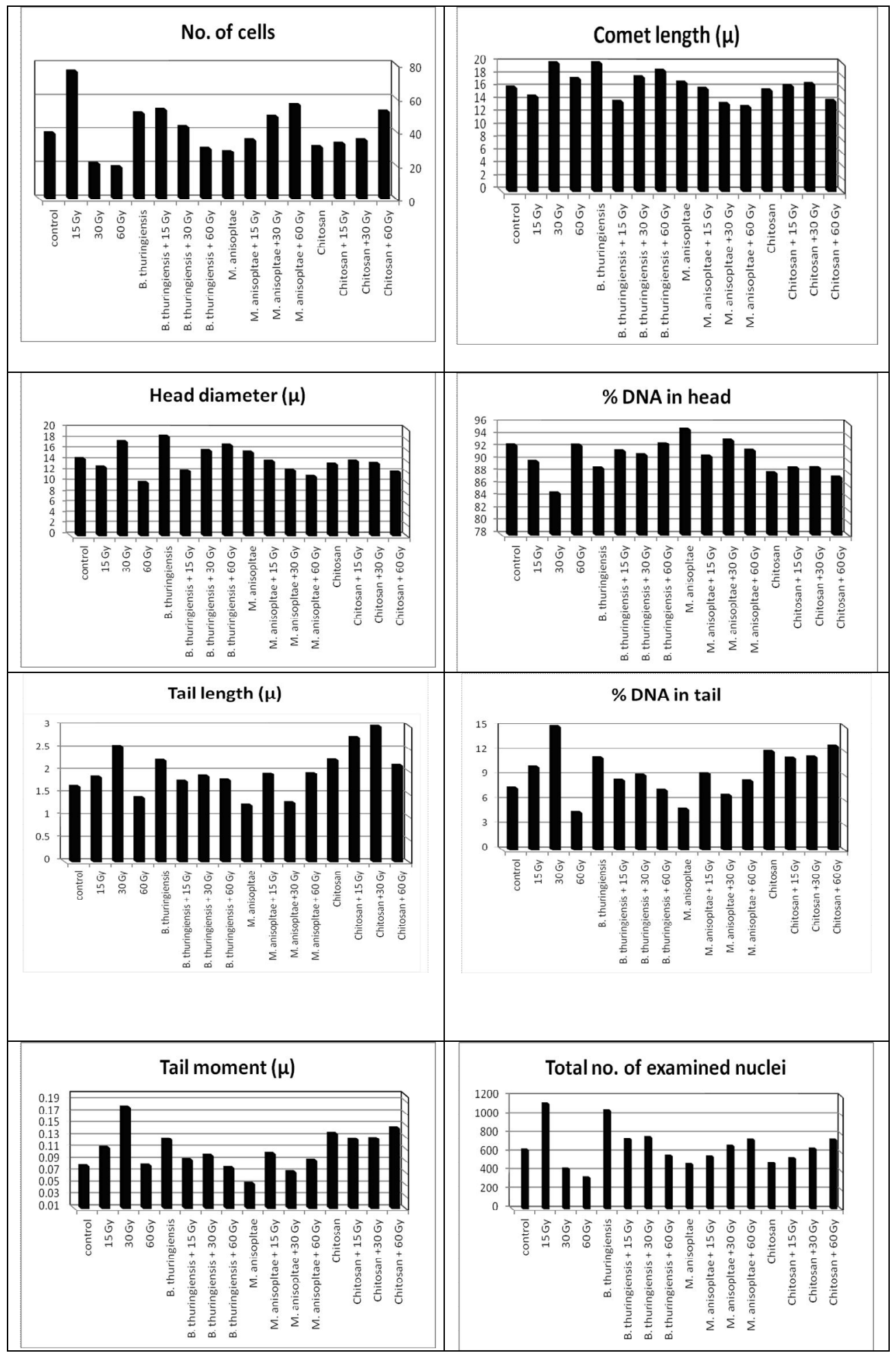


898 COMET ASSAY PARAMETERS OF SPODOPTERA LITTORALIS (BOISD.) LARVAE RESISTANCE SYSTEM CELLS AS AFFECTED BY DIFFERENT COMPOUNDS EXPOSED TO GAMMA IRRADIATION

Table 4. Comet assay different grades of $S$. littoralis larvae resistance system cells as affected by different compounds with gamma irradiation.

\begin{tabular}{|c|c|c|c|c|c|c|c|c|c|}
\hline \multirow{2}{*}{ Treatments } & \multirow{2}{*}{$\begin{array}{c}\text { Total no. } \\
\text { of } \\
\text { examined } \\
\text { nuclei }\end{array}$} & \multicolumn{2}{|c|}{ Grade 0} & \multicolumn{2}{|c|}{ Grade 1} & \multicolumn{2}{|c|}{ Grade 2} & \multicolumn{2}{|c|}{ Grade 3} \\
\hline & & No. & $\%$ & No. & $\%$ & No. & $\%$ & No. & $\%$ \\
\hline Control & $\begin{array}{c}628.6 \\
d\end{array}$ & $\begin{array}{c}390.2 \\
a b\end{array}$ & $\begin{array}{c}62.07 \\
a\end{array}$ & $\begin{array}{l}230 \\
\text { bcde }\end{array}$ & $\begin{array}{c}36.59 \\
\text { abcde }\end{array}$ & $\begin{array}{c}8.36 \\
f\end{array}$ & $\begin{array}{c}1.33 \\
d\end{array}$ & 0 & 0 \\
\hline 15 Gy & $\begin{array}{c}1122 \\
a\end{array}$ & $\begin{array}{c}440.2 \\
\mathrm{a}\end{array}$ & $\begin{array}{c}39.23 \\
a b c\end{array}$ & $\begin{array}{c}403.6 \\
a b\end{array}$ & $\begin{array}{c}35.96 \\
\text { bcde }\end{array}$ & $\begin{array}{c}248.4 \\
a\end{array}$ & $\begin{array}{c}22.14 \\
a b c\end{array}$ & 0 & 0 \\
\hline $30 \mathrm{~Gy}$ & $\begin{array}{c}424.8 \\
h\end{array}$ & $\begin{array}{c}108.4 \\
\mathrm{fg}\end{array}$ & $\begin{array}{c}25.51 \\
c d\end{array}$ & $\begin{array}{c}205.9 \\
\text { cde }\end{array}$ & $\begin{array}{c}48.47 \\
a b c\end{array}$ & $\begin{array}{c}72.0 \\
d\end{array}$ & $\begin{array}{c}16.95 \\
\text { bod }\end{array}$ & 0 & 0 \\
\hline $60 \mathrm{~Gy}$ & $\begin{array}{c}333.4 \\
i\end{array}$ & $\begin{array}{c}190.8 \\
\text { def }\end{array}$ & $\begin{array}{c}57.24 \\
a b\end{array}$ & $\begin{array}{c}109.4 \\
\mathrm{e}\end{array}$ & $\begin{array}{c}32.83 \\
\text { cde }\end{array}$ & $\begin{array}{c}33.12 \\
\text { ef }\end{array}$ & $\begin{array}{c}9.935 \\
c d\end{array}$ & 0 & 0 \\
\hline $\begin{array}{c}\text { B. } \\
\text { thuringiensis }\end{array}$ & $\begin{array}{c}1050 \\
b\end{array}$ & $\begin{array}{c}403.9 \\
\text { a }\end{array}$ & $\begin{array}{c}38.44 \\
a b c\end{array}$ & $\begin{array}{c}462.9 \\
a\end{array}$ & $\begin{array}{c}44.06 \\
\text { abcd }\end{array}$ & $\begin{array}{c}183.9 \\
b\end{array}$ & $\begin{array}{c}17.51 \\
\text { bod }\end{array}$ & 0 & 0 \\
\hline $\begin{array}{c}\text { B. } \\
\text { thuringiensis } \\
+15 \mathrm{~Gy} \\
\end{array}$ & $\begin{array}{c}740.5 \\
c\end{array}$ & $\begin{array}{c}250.9 \\
\text { cde }\end{array}$ & $\begin{array}{c}33.88 \\
\text { abcd }\end{array}$ & $\begin{array}{c}312.1 \\
\text { abcd }\end{array}$ & $\begin{array}{l}42.15 \\
\text { abcde }\end{array}$ & $\begin{array}{c}177.5 \\
\text { bc }\end{array}$ & $\begin{array}{c}23.97 \\
a b c\end{array}$ & 0 & 0 \\
\hline $\begin{array}{c}\text { B. } \\
\text { thuringiensis } \\
+30 \mathrm{~Gy}\end{array}$ & $\begin{array}{c}765.7 \\
c\end{array}$ & $\begin{array}{c}312.1 \\
\text { bc }\end{array}$ & $\begin{array}{c}40.76 \\
a b c\end{array}$ & $\begin{array}{c}337.3 \\
a b c\end{array}$ & $\begin{array}{c}44.05 \\
\mathrm{abcd}\end{array}$ & $\begin{array}{c}86.4 \\
d\end{array}$ & $\begin{array}{c}11.28 \\
c d\end{array}$ & $\begin{array}{c}29.88 \\
\text { bc }\end{array}$ & $\begin{array}{c}3.902 \\
b c\end{array}$ \\
\hline $\begin{array}{c}\text { B. } \\
\text { thuringiensis } \\
+60 \mathrm{~Gy} \\
\end{array}$ & $\begin{array}{c}564.8 \\
\mathrm{e}\end{array}$ & $\begin{array}{c}239.4 \\
\text { cde }\end{array}$ & $\begin{array}{c}42.38 \\
a b c\end{array}$ & $\begin{array}{c}268.9 \\
\text { bcde }\end{array}$ & $\begin{array}{c}47.61 \\
a b c\end{array}$ & $\begin{array}{c}56.52 \\
\text { de }\end{array}$ & $\begin{array}{c}10.0 \\
c d\end{array}$ & 0 & 0 \\
\hline $\begin{array}{c}\text { M. } \\
\text { anisopltae }\end{array}$ & $\begin{array}{c}472.7 \\
\text { gh }\end{array}$ & $\begin{array}{c}280.4 \\
\text { cd }\end{array}$ & $\begin{array}{c}59.33 \\
\text { a }\end{array}$ & $\begin{array}{c}138.2 \\
\text { de }\end{array}$ & $\begin{array}{c}29.25 \\
\text { de }\end{array}$ & $\begin{array}{c}54.0 \\
\text { de }\end{array}$ & $\begin{array}{c}11.42 \\
\text { cd }\end{array}$ & 0 & 0 \\
\hline $\begin{array}{c}\text { M. } \\
\text { anisopltae + } \\
15 \mathrm{~Gy}\end{array}$ & $\begin{array}{c}557.6 \\
\mathrm{e}\end{array}$ & $\begin{array}{c}165.6 \\
\text { ef }\end{array}$ & $\begin{array}{c}29.69 \\
\text { bcd }\end{array}$ & $\begin{array}{c}282.2 \\
\text { abcde }\end{array}$ & $\begin{array}{c}50.61 \\
\mathrm{ab}\end{array}$ & $\begin{array}{c}78.12 \\
d\end{array}$ & $\begin{array}{c}14.0 \\
\text { bod }\end{array}$ & $\begin{array}{c}31.68 \\
\text { bc }\end{array}$ & $\begin{array}{c}5.681 \\
a b c\end{array}$ \\
\hline $\begin{array}{c}\text { M. } \\
\text { anisopltae + } \\
30 \mathrm{~Gy}\end{array}$ & $\begin{array}{c}668.5 \\
d\end{array}$ & $\begin{array}{c}269.6 \\
c d\end{array}$ & $\begin{array}{c}40.33 \\
\text { abc }\end{array}$ & $\begin{array}{c}296.3 \\
\text { abcd }\end{array}$ & $\begin{array}{c}44.32 \\
a b c d\end{array}$ & $\begin{array}{c}69.48 \\
d\end{array}$ & $\begin{array}{c}10.39 \\
c d\end{array}$ & 0 & 0 \\
\hline $\begin{array}{c}\text { M. } \\
\text { anisopltae + } \\
60 \mathrm{~Gy}\end{array}$ & $\begin{array}{c}732.6 \\
c\end{array}$ & $\begin{array}{l}225.0 \\
\text { cde }\end{array}$ & $\begin{array}{c}30.71 \\
\text { bcd }\end{array}$ & $\begin{array}{l}271.1 \\
\text { bcde }\end{array}$ & $\begin{array}{c}37.00 \\
\text { abcde }\end{array}$ & $\begin{array}{c}217.4 \\
a\end{array}$ & $\begin{array}{c}29.68 \\
a b\end{array}$ & $\begin{array}{c}19.08 \\
c\end{array}$ & $\begin{array}{c}2.604 \\
c\end{array}$ \\
\hline Chitosan & $487.1^{\mathrm{fg}}$ & $192.2^{\text {def }}$ & $39.47^{\mathrm{abc}}$ & $127.1^{\mathrm{de}}$ & $26.09^{e}$ & $148.3^{c}$ & $30.45_{a b}$ & $19.44^{c}$ & $3.991^{b c}$ \\
\hline $\begin{array}{c}\text { Chitosan + } \\
15 \text { Gy }\end{array}$ & $\begin{array}{c}539.6 \\
\text { ef }\end{array}$ & $\begin{array}{c}50.04 \\
\mathrm{~g} \\
\end{array}$ & $\begin{array}{c}9.273 \\
d\end{array}$ & $\begin{array}{c}292.4 \\
\text { abcde }\end{array}$ & $\begin{array}{c}54.17 \\
\text { a } \\
\end{array}$ & $\begin{array}{c}187.2 \\
\text { b } \\
\end{array}$ & $\begin{array}{c}34.69 \\
\mathrm{a} \\
\end{array}$ & $\begin{array}{c}10.08 \\
c\end{array}$ & $\begin{array}{c}1.868 \\
\mathrm{c}\end{array}$ \\
\hline $\begin{array}{c}\text { Chitosan + } \\
30 \mathrm{~Gy} \\
\end{array}$ & $\begin{array}{c}639.6 \\
d \\
\end{array}$ & $\begin{array}{c}50.04 \\
\mathrm{~g} \\
\end{array}$ & $\begin{array}{c}7.823 \\
d \\
\end{array}$ & $\begin{array}{c}292.4 \\
\text { abcde }\end{array}$ & $\begin{array}{c}45.71 \\
\text { ab }\end{array}$ & $\begin{array}{c}247.2 \\
\text { a } \\
\end{array}$ & $\begin{array}{c}38.65 \\
\mathrm{a} \\
\end{array}$ & $\begin{array}{c}50.08 \\
\mathrm{ab} \\
\end{array}$ & $\begin{array}{c}7.829 \\
\text { ab } \\
\end{array}$ \\
\hline $\begin{array}{c}\text { Chitosan + } \\
60 \mathrm{~Gy}\end{array}$ & $\begin{array}{c}732.9 \\
\mathrm{c} \\
\end{array}$ & $\begin{array}{c}202.7 \\
\text { de }\end{array}$ & $\begin{array}{c}27.65 \\
c d\end{array}$ & $\begin{array}{c}289.8 \\
\text { abcde }\end{array}$ & $\begin{array}{c}39.54 \\
\text { abcde }\end{array}$ & $\begin{array}{c}171.7 \\
\text { bc }\end{array}$ & $\begin{array}{c}23.43 \\
a b c\end{array}$ & $\begin{array}{c}61.56 \\
\mathrm{a} \\
\end{array}$ & $\begin{array}{c}8.399 \\
\text { a } \\
\end{array}$ \\
\hline L.S.D. 0.05 & 55.26 & 83.86 & 24.27 & 157.44 & 14.877 & 29.82 & 15.03 & 23.02 & 3.744 \\
\hline P. & 0 & 0 & 0.0021 & 0.0048 & 0.0158 & $\mathbf{0}$ & 0.001 & 0.003 & 0.014 \\
\hline Significant & $* * *$ & $* * *$ & $* *$ & $* *$ & $*$ & $* * *$ & $* * *$ & $* *$ & $*$ \\
\hline $\mathbf{F}$ & 118.9 & 15.61 & 3.326 & 2.966 & 2.464 & 57.73 & 3.989 & 5.818 & 4.125 \\
\hline S.S & 20046 & 6767 & 1744 & 6854 & 5517 & 2886 & 7501 & 8447 & 177.2 \\
\hline $\begin{array}{c}\text { Error mean } \\
\text { square }\end{array}$ & 1104.0 & 2542.3 & 213.0 & 8961.3 & 80.012 & 321.5 & 81.68 & 172.7 & 4.571 \\
\hline
\end{tabular}


Fig. 2. Comet assay grades (DNA destruction) of $S$. littoralis larvae resistance system cells as affected by different compounds with gamma irradiation.

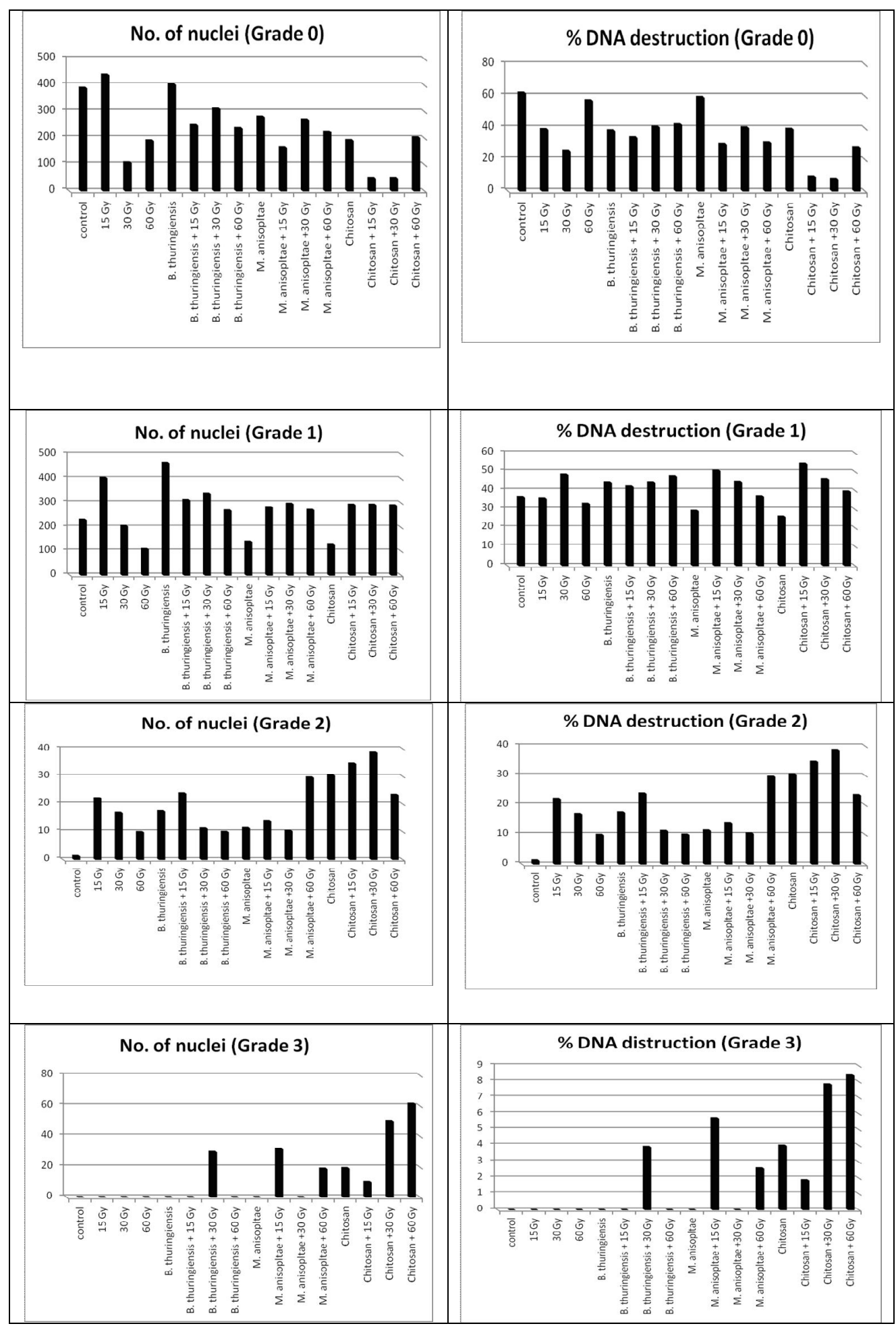


900 COMET ASSAY PARAMETERS OF SPODOPTERA LITTORALIS (BOISD.) LARVAE RESISTANCE SYSTEM CELLS AS AFFECTED BY DIFFERENT COMPOUNDS EXPOSED TO GAMMA IRRADIATION

Table 5. Comet assay different grades of $S$. littoralis larvae resistance system cells affected by different compounds with gamma irradiation compared to control.

\begin{tabular}{|c|c|c|c|c|c|c|c|c|c|}
\hline \multirow[b]{2}{*}{ Treatments } & \multirow{2}{*}{$\begin{array}{l}\text { Total no. } \\
\text { of } \\
\text { examined } \\
\text { nuclei }\end{array}$} & \multicolumn{2}{|c|}{ Grade 0} & \multicolumn{2}{|c|}{ Grade 1} & \multicolumn{2}{|c|}{ Grade 2} & \multicolumn{2}{|c|}{ Grade 3} \\
\hline & & No. & $\%$ & No. & $\%$ & No. & $\%$ & No. & $\%$ \\
\hline Control & 628.56 & 390.2 & 62.07 & 230.0 & 36.59 & 8.36 & 1.33 & 0 & 0 \\
\hline 15 Gy & +493.6 & +50.0 & -22.8 & +173 & -0.63 & +240 & +20.8 & 0 & 0 \\
\hline $30 \mathrm{~Gy}$ & -203.8 & -281 & -36.6 & -24.1 & +11.9 & +63.6 & +15.6 & 0 & 0 \\
\hline $60 \mathrm{~Gy}$ & -295.2 & -199 & -4.83 & -120 & -3.76 & +24.8 & +8.61 & 0 & 0 \\
\hline $\begin{array}{c}\text { B. } \\
\text { thuringiensis }\end{array}$ & +422.3 & +13.8 & -23.6 & +232 & +8.37 & +175 & +16.2 & 0 & 0 \\
\hline $\begin{array}{c}\text { B. } \\
\text { thuringiensis } \\
+15 \mathrm{~Gy} \\
\end{array}$ & +111.9 & -139 & -28.2 & +82.1 & +5.56 & +169 & +22.6 & 0 & 0 \\
\hline $\begin{array}{c}\text { B. } \\
\text { thuringiensis } \\
+30 \mathrm{~Gy}\end{array}$ & +137.2 & -78 & -21.3 & +107 & +7.46 & +78.0 & +9.95 & +29.9 & +3.90 \\
\hline $\begin{array}{c}\text { B. } \\
\text { thuringiensis } \\
+60 \mathrm{~Gy}\end{array}$ & -63.72 & -150 & -19.7 & +38.9 & +11.0 & +48.2 & +8.68 & 0 & 0 \\
\hline M. anisopltae & -155.9 & -109 & -2.74 & -91.8 & -7.34 & +45.6 & +10.1 & 0 & 0 \\
\hline $\begin{array}{c}\text { M. anisopltae } \\
+ \\
15 \mathrm{~Gy} \\
\end{array}$ & -70.92 & -224 & -32.4 & +52.2 & +14.0 & +69.8 & +12.7 & +31.7 & +5.68 \\
\hline $\begin{array}{c}\text { M. anisopltae } \\
+ \\
30 \mathrm{~Gy} \\
\end{array}$ & +39.96 & -120 & -21.7 & +66.2 & +7.73 & +61.1 & +9.06 & 0 & 0 \\
\hline $\begin{array}{c}\text { M. anisopltae } \\
+ \\
60 \mathrm{~Gy} \\
\end{array}$ & +104.0 & -165 & -31.4 & +41.0 & +0.41 & +209 & +28.4 & +19.1 & +2.60 \\
\hline Chitosan & -141.5 & -197 & -22.6 & -102 & -10.5 & +139 & +29.1 & +19.4 & +3.99 \\
\hline $\begin{array}{c}\text { Chitosan + } \\
15 \mathrm{~Gy} \\
\end{array}$ & -88.92 & -340 & -52.8 & +62.4 & +17.6 & +178 & +33.4 & +10.1 & +1.87 \\
\hline $\begin{array}{c}\text { Chitosan + } \\
30 \mathrm{~Gy} \\
\end{array}$ & 11.08 & -340 & -54.3 & +62.4 & +9.12 & +238 & +37.3 & +50.1 & +7.83 \\
\hline $\begin{array}{c}\text { Chitosan + } \\
60 \mathrm{~Gy}\end{array}$ & +104.4 & -187 & -34.4 & +59.8 & +2.95 & +163 & +22.1 & +61.6 & +8.39 \\
\hline
\end{tabular}

Moreover, since the comet assay allows measurement of an effect on each observed nucleus, we must question whether the average response of all the cells (using classical mean comparison tests) is the best indicator of genotoxic potential or whether distribution comparison tests must be developed to take into account the different responses of the individual nuclei. Another question concerns the fact that small cell samples may not be representative of the total cell population (Tice et al., 1991).

Actually, published studies show that 50 or 100 cells per experimental condition are generally analyzed. Despite the lack of standardization of the method, the comet assay offers a lot of advantages. Of course, the comet assay does not require uptake 
of radio labeled DNA precursors (Ostling and Johanson, 1984). Different reviews showed its sensitivity for detecting DNA damage and its rapidity. In individual cells, it allows quantification of different responses from single-strand breakages to apoptosis. Other advantages are the use of extremely small cell samples and that virtually any eukaryote cell population is amenable to analysis (Tice et al., 1991).

Fig. 3. Comet assay of $S$. littoralis larvae resistance system cells exposed to gamma irradiation.

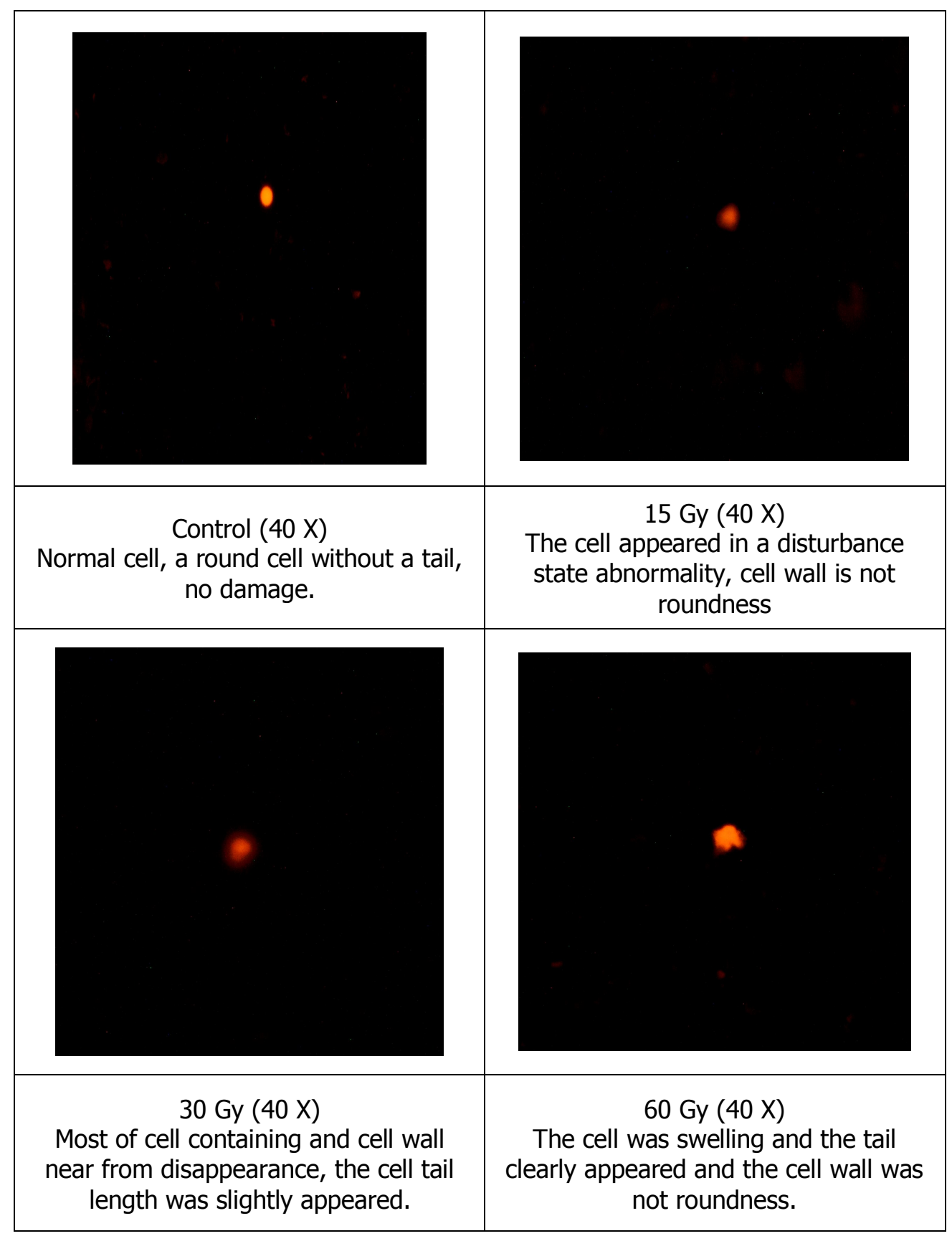



SYSTEM CELLS AS AFFECTED BY DIFFERENT COMPOUNDS EXPOSED TO GAMMA IRRADIATION

Fig. 4. Comet assay of $S$. littoralis larvae resistance system cells as affected by $B$. thuringiensis exposed to gamma irradiation.

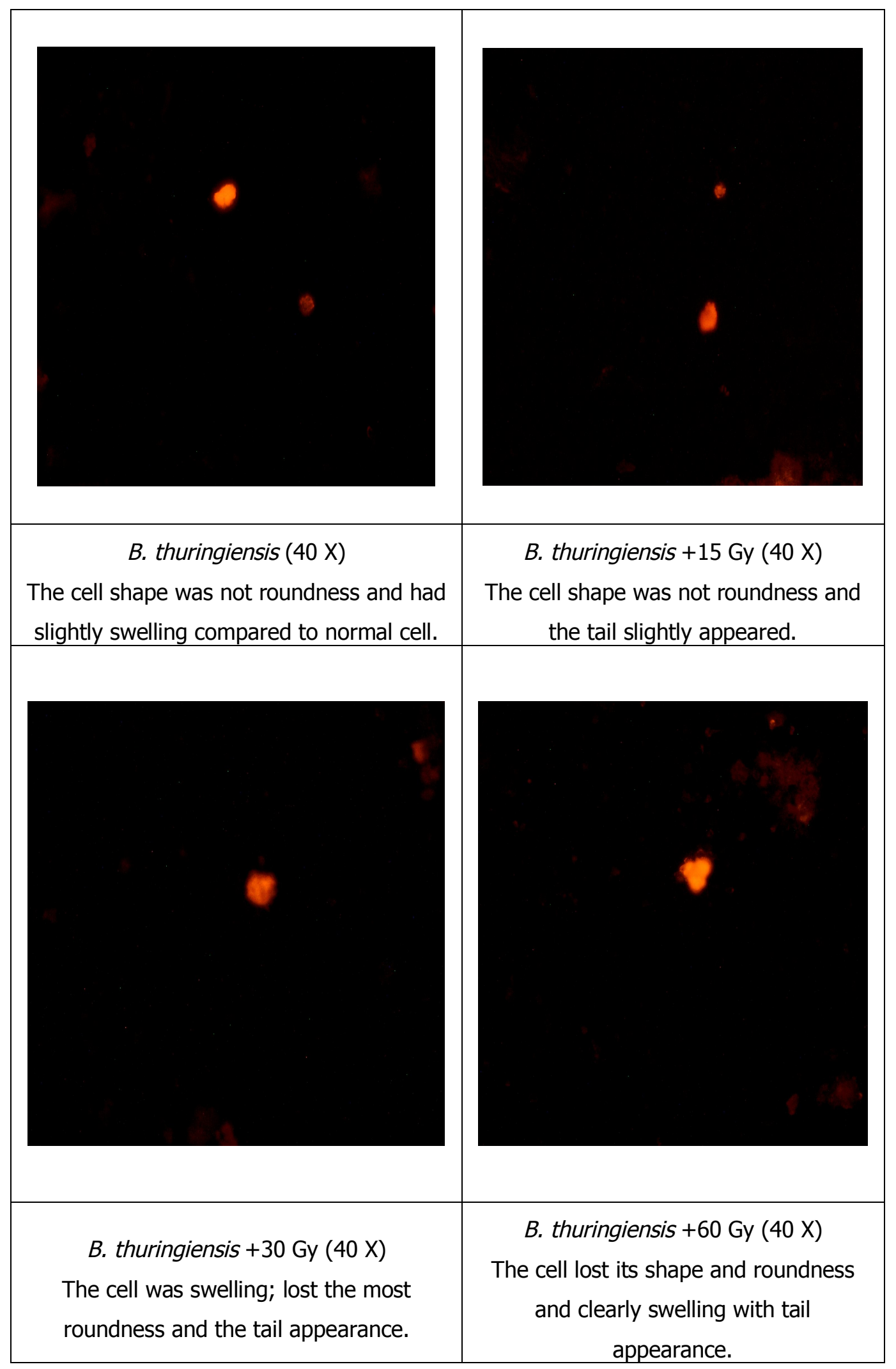


Fig. 5. Comet assay of $S$. littoralis larvae resistance system cells as affected by $M$. anisopltae exposed to gamma irradiation.

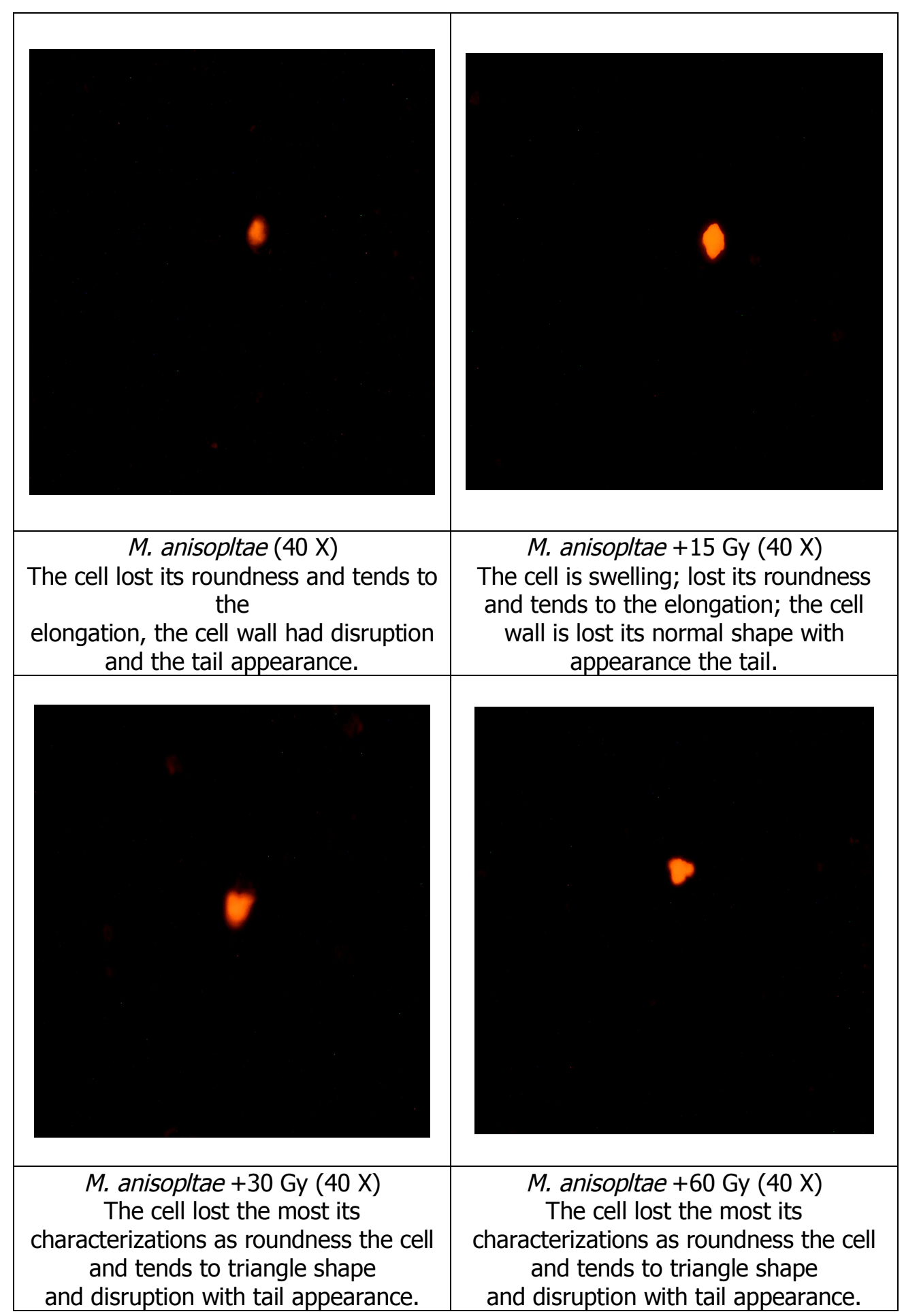


Fig. 6. Comet assay of $S$. littoralis larvae resistance system cells as affected by Chitosan exposed to gamma irradiation.

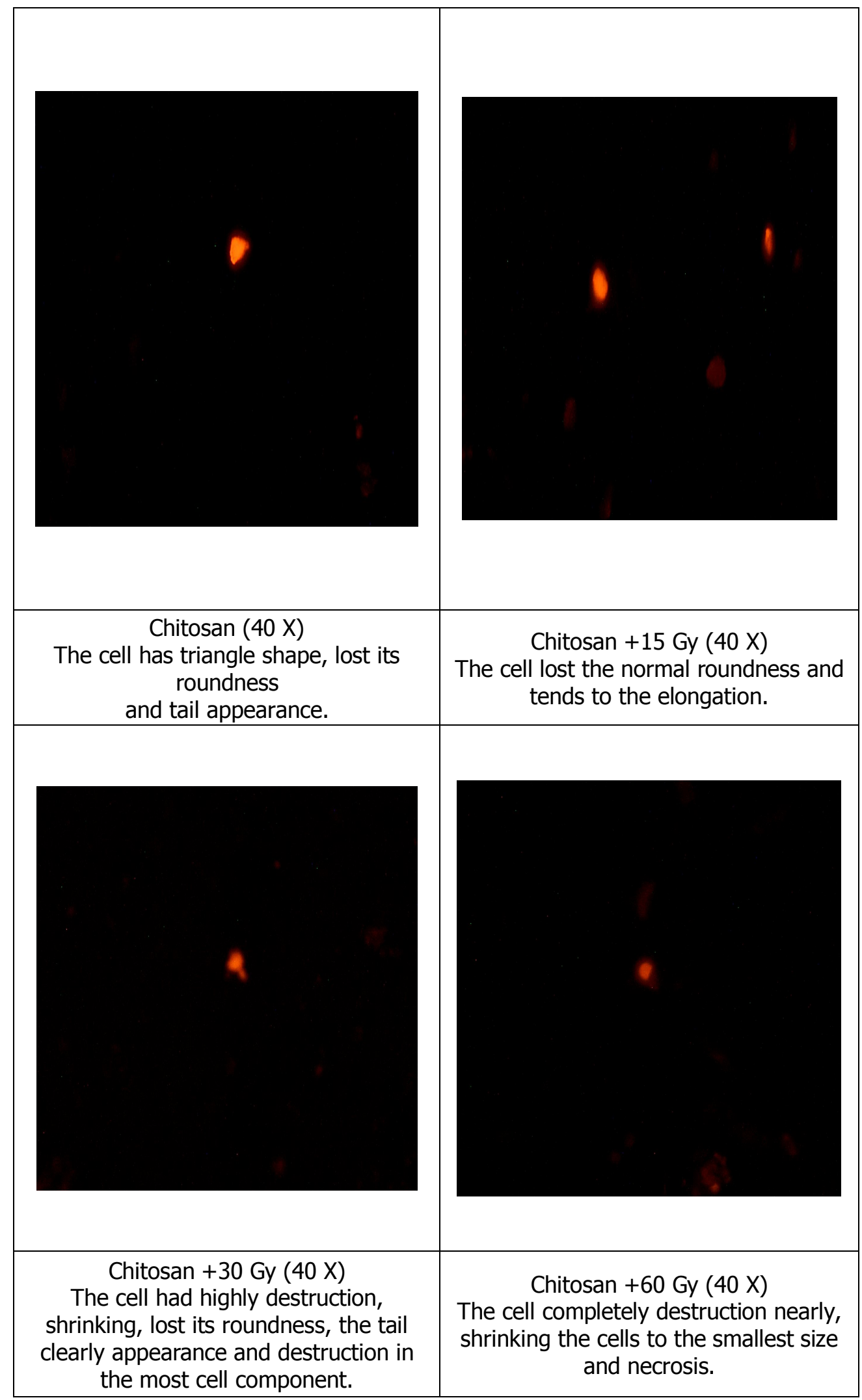


Furthermore, to see an effect in the comet assay there is no need for cell division, whereas micronuclei can be detected only after mitosis (Belpaeme et al., 1996). The most important disadvantage of the assay concerns the necessity for single cell suspensions.

The relationships between DNA structural alterations or genome dis-functioning and effects at a level of organization higher than that of individuals are not straightforward. To predict effects at the population level, genome approaches need to be complemented with phenotypic studies for growth, reproduction and juvenile sensitivity. An integration of molecular and physiological data should optimize the knowledge gained from use of these molecular tools.

\section{REFERENCES}

1. Amaeze, N.H.; S. Schnell; O. Sozeri; A.A. Otitoloju; R.I. Egonmwan; V.M. Arlt and N.R. Bury 2015. Cytotoxic and genotoxic responses of the RTgill-W1 fish cells in combination with the yeast oestrogen screen to determine the sediment quality of Lagos lagoon. Niger. Mutagen. 30 (1):117-127.

2. Amer, R.A. 2006. Combination of gamma irradiation with Bacillus thuringiensis (Kurs.) and the synergistic effect of two bioinsecticid mixture for controlling the pink bollworm, Pectinophora gossypiella (Saund.) in cotton bolls. J.Egypt.Ger.Soc.Zool. 51: 1-13.

3. Amer, R.A.; Sh.S. Yacoub; G.M. Nouh and A.E. Hatem 2015. Gamma irradiation to potentiate some bio-agents compounds against the cotton leaf worm, Spodoptera littoralis (Boisd.) (Lepidoptera: Noctuidae). Egyptian Journal Biological Pest Control, 25(2): 445-455.

4. Amer, R.A.; S.S. Abdel-Samad and M.A. Ahmed 2011. Toxicity of Beauveria bassiana (Balsamo) exposed to gamma irradiation doses on some pests. J. Egypt. Ger. Soc. Zool. 63: 33-47. The $19^{\text {th }}$ international conference 30 April-2 May 2011, Faculty of Science, Beni-Sueif University.

5. Amer, R.A.; M.A. Ahmed and A.E .Hatem 2012. Effect of gamma irradiation combined with B. T. biocide treatments on some insect pests in laboratory. Egypt. J. Agric. Res., 90 (3): 1041-1053.

6. Badawy, M.E.; E.I .Rabea; T.M. Rogge; C.V. Steven; W. Steurbaut; M. Hofte and G. Smagghe 2005. Fungicidal and insecticidal activity of O-acyl chitosan derivatives. polymer Bull., 54: 279-289.

7. Belpaeme, K.; K. Delbeke; L. Zhu and M. Kirsch-Volders 1996. Cytogenetic studies of PCB77 on brown trout (Salmo trutta, fario) using the micronucleus test and the alkaline comet assay. Mutagenesis, 11:485-492.

8. Collins, A.R.; V.L. Dobson; M. Dusinska; G. Kennedy and R. Stetina 1997. The comet assay: what can it really tell us? Mutat Res, 375:183-193.

9. Costat Statistical Software (1990). Microcomputer program analysis version 4.20, cohort Software, Berkeley, CA.

10.Duncan, D.B. 1955. Multiple ranges and multiple F.test. Biomerics. 11:1-42. 
906 COMET ASSAY PARAMETERS OF SPODOPTERA LITTORALIS (BOISD.) LARVAE RESISTANCE SYSTEM CELLS AS AFFECTED BY DIFFERENT COMPOUNDS EXPOSED TO GAMMA IRRADIATION

11.El-Defrawi, M. E. ; A. Toppozada; N. Mansour and M. Zeid 1964. Toxicological studies on the Egyptian cotton leafworm, Prodenia litura I. Susceptibility of different larval instars to insecticides. J. Econ. Entomol. 57: 591-593.

12.El-Gendy, I.R.; H.M. Nasr; M. El-Badawy and E. Rabea 2014. Toxic and biochemical effects for certain natural compounds on the peach fruit fly, Bacterocera zonata (Diptera, Tephritidae). Am.J.Biochem. Mol.Biol., 4(3): 112121.

13.Finney. D.J. 1971. Probit analysis. $3^{\text {rd }}$ Edn. Cambridge University press, Cambridge, UK., pages: 318.

14.Gabarty, A.; S.M El-Sonbaty and A.A. Ibrahim 2013. Synergistic effect of gamma radiation and entomopathogenic fungi Beauveria bassiana and Metarhizium anisopliae on the humoral immune enzyme response in cotton leaf worm Spodoptera littolaris (Boisd). Egypt. Acad. J. Biolog. Sci., 6(3): 1-10.

15.Hosny, M.M. and R.R. Isshak 1967. New approaches to the ecology and control of three major cotton pests in U. A. R. Part 1: Factors stimulating the outbreaks of the cotton leafworm in U. A. R. and the principle of its predication. U.A.R. Minist. Agric. Tech. Bull., 1: 1-36.

16.Olive, P.L. and J.P. Banath 2006. The comet assay: a method to measure DNA damage in individual cells. Nat. Protoc., 1 (1): 23-29.

17.Ostling, O. and K.J. Johanson 1984. Micro electrophoretic study of radiationinduced DNA damages in individual mammalian cells. Biochem. Biophys. Res. Commun., 123: 291-298.

18.Rabea, E.I.; M.E. Badawy; C.V. Stevens; G. Smagghe and W. Steurbaut 2003. Chitosan as antimicrobial agent: Applications and mode of action. Biomacro molecules, 4(6): 1457- 1465.

19.Singh, N.P.; M.T. McCoy; R.R. Tice and E.L. Schneider 1988. A simple technique for quantization of low levels of DNA damage in individual cells. Exp Cell Res 175:184 -191.

20.Sun, Y. P. 1950. Toxicity index on improved method of comparing the relative toxicity of insecticides. J. Econ. Entomol., 43: 45-53.

21.Tice, R.R. 1995. The single cell gel/comet assay: a microgel electrophoretic technique for the detection of DNA damage and repair in individual cells. In Phillipps DH, Venitt S (eds): Environmental Mutagenesis. Oxford: Bios Scientific Publishers, pp 315-339.

22.Tice, R.R.; P.W. Andrews; O. Hirai and N.P. Singh 1991. The single cell gel (SCG) assay: an electrophoresis technique for the detection of DNA damage in individual cells. Adv Exp Med Biol, 283:157-164. 


\section{قياسات تحليل الكوميت للخلايا المسئولة عن مقاومة يرقات دودة

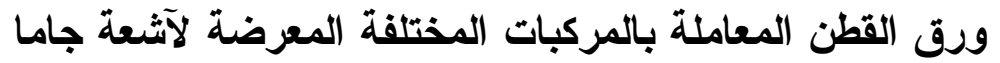

رضا عبد الجليل عامر' ، محمد سالم محمد' ، داليا عبد الله عبد السلام' و نانسى حسن نجيب'

$$
\begin{aligned}
& \text { 'معهد بحوث وقاية النباتات - مركز البحوث الزراعية - دقى - جبزة- ج.م-م:ع. }
\end{aligned}
$$

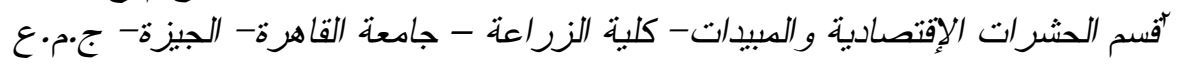

يعرف تحليل الكوميت بأنه التفريد الكهربائى للخلايا المنفردة ( SCGE) أو التفريد الكهربائى الدقيق (MGE) الذى يقيس أساسا مدى تحطم شريط الحامض النووى طبقا لنوع الخلايا الناتجة فى (لنى

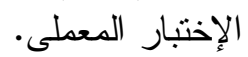
و الهدف الرئيسى لهذه الدراسة هو قياس السمية الجينية للخلايا المسئولة عن مقاومة يرقات دودة ورق القطن للمركبات المختلفة وذللك بحدوث إستخلاص للخلايا المسئولة عن مقاومة الآفة للمبيدات و المتأثزة بثلاثة معاملات لمركبات بكتيريا الــ B. B.

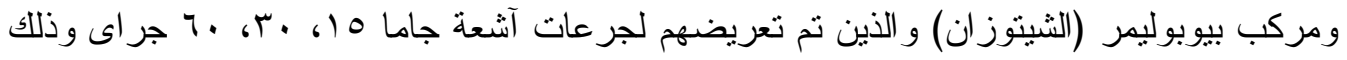

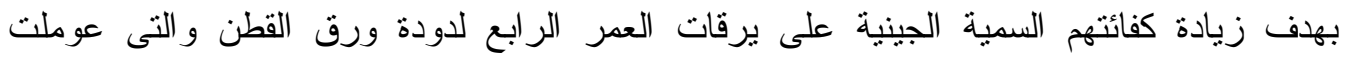
بالتزكيز النصفى المميت للمركبات السالفة الذكر .

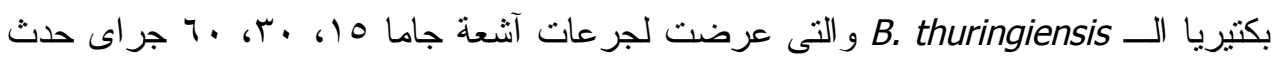

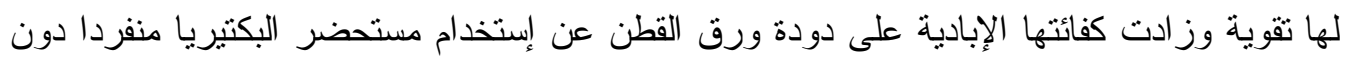

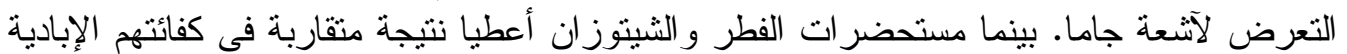

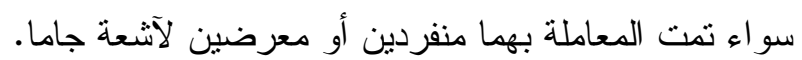

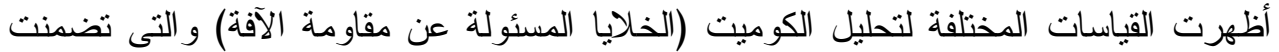

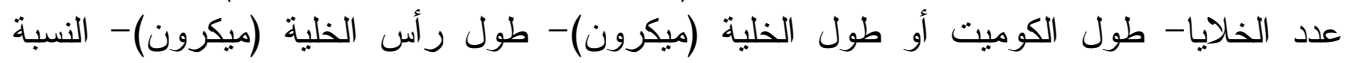

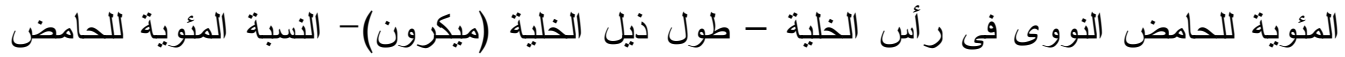

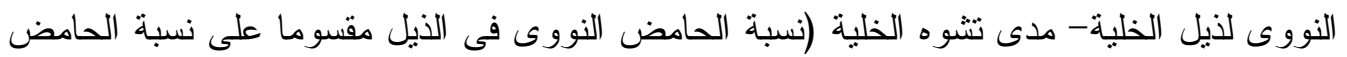

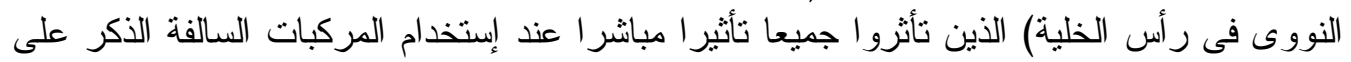

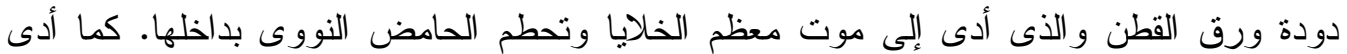

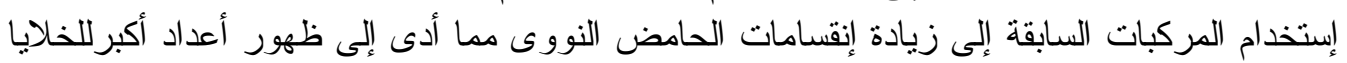

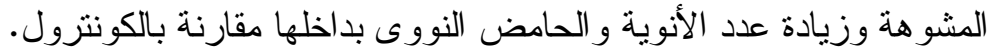

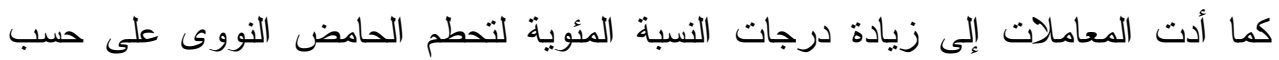

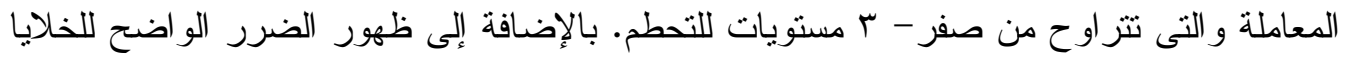

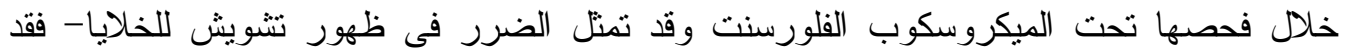

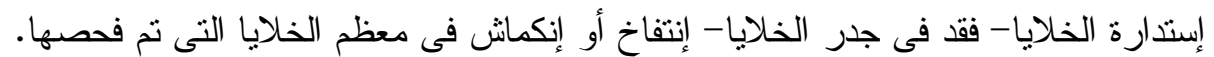

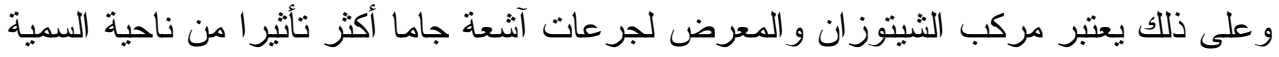

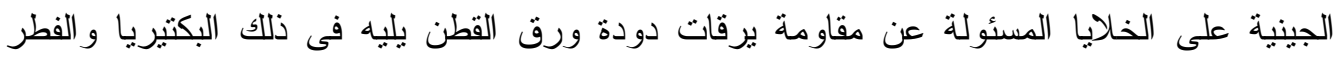

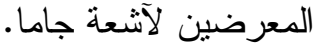


